\title{
Smallsteps: de uitspraak, de Nederlandse rechtspraak en voorgestelde regelgeving
}

\author{
C. de Groot
}

\section{Inleiding}

Op 22 juni 2017 beantwoordde het Hof van Justitie van de Europese Unie (hierna ook: het Europese Hof van Justitie) in de Smallsteps-uitspraak vragen die de Rechtbank Midden-Nederland op 14 februari 2016 aan het Hof had voorgelegd. Die vragen gingen over de uitleg van de Europese richtlijn betreffende het behoud van de rechten van de werknemers bij overgang van ondernemingen. Die richtlijn bepaalt dat bij een overgang van een onderneming de rechten en verplichtingen uit arbeidsovereenkomsten automatisch mee overgaan naar de verkrijger van de onderneming. De richtlijn bevat een uitzonderingsbepaling: de werknemersbescherming is niet van toepassing als de vervreemder van de onderneming failliet is verklaard. De rechtbank wilde weten of deze uitzonderingsbepaling ook geldt als de overgang van de onderneming al is voorbereid voorafgaand aan het faillissement, maar daadwerkelijk plaatsvindt tijdens het faillissement. Dit deed zich in dit geval voor omdat het faillissement was voorbereid door middel van een prepackaged deal (kortweg: een pre-pack). Het Europese Hof van Justitie besliste (kort gezegd) dat deze gang van zaken een overgang van een onderneming vormde in de zin van de richtlijn en dat de uitzonderingsbepaling niet van toepassing was. Hierna komt het volgende aan de orde: een korte bespreking van de richtlijn (par. 2), de gang van zaken in de Smallsteps-zaak (par. 3), de uitspraak van het Europese Hof van Justitie (par. 4), een kritische bespreking van de Nederlandse rechtspraak (par. 5) en van voorgestelde regelgeving (par. 6), en een conclusie (par. 7).

\section{De richtlijn}

De Europese richtlijn betreffende het behoud van de rechten van de werknemers bij overgang van ondernemingen dateert uit 1977. Dit was Richtlijn 77/187/EEG 
van 14 februari 1977 en is, na Richtlijn 98/50/EG uit 1998, nu Richtlijn 2001/23/ EG van 12 maart 2001. ${ }^{1}$ Die laatste richtlijn bepaalt in art. 3 lid 1:

'De rechten en verplichtingen welke voor de vervreemder voortvloeien uit de op het tijdstip van de overgang bestaande arbeidsovereenkomst of arbeidsbetrekking, gaan door deze overgang op de verkrijger over.'

Van een overgang van een onderneming is sprake als die overgang het resultaat is van 'een overdracht krachtens overeenkomst' of van 'een fusie' (art. 1 lid 1 onder a). Overigens bepaalt art. 4 lid 1 van de richtlijn dat de overgang van een onderneming op zichzelf geen ontslagreden mag zijn, tenzij het gaat om ontslagen om economische, technische of organisatorische redenen. Art. 5 van de richtlijn bevat de faillissementsuitzondering. De richtlijn is (tenzij de nationale wetgeving voor het tegendeel kiest) niet van toepassing in faillissementsprocedures (of soortgelijke procedures) die tot doel hebben het vermogen van de vervreemder te liquideren (art. 5 lid 1). De preambule bij de richtlijn uit 1977 formuleerde het doel van de richtlijn als volgt: 'dat voorzieningen nodig zijn om de werknemers bij verandering van ondernemer te beschermen, in het bijzonder om het behoud van hun rechten veilig te stellen'. De richtlijn uit 1998 introduceerde de faillissementsuitzondering. De preambule bij deze richtlijn gaf als motivering van de uitzondering: 'dat het de lidstaten, teneinde het voortbestaan van insolvente ondernemingen te verzekeren, uitdrukkelijk moet worden toegestaan (...) Richtlijn 77/187/EEG niet toe te passen op een overgang in het kader van een liquidatieprocedure'. De faillissementsuitzondering is (zonder verdere opmerkingen daarover in de preambule) gehandhaafd in de richtlijn uit 2001. De richtlijn is in Nederland geïmplementeerd in (met name) titel 10 ('Arbeidsovereenkomst'), afdeling 8 ('Rechten van de werknemer bij overgang van een onderneming') van Boek 7 Burgerlijk Wetboek (BW). Deze afdeling bestaat uit art. 7:662 tot en met 7:666a BW. De faillissementsuitzondering staat in art. 7:666 onder a BW en is geformuleerd voor het geval 'de werkgever in staat van faillissement is verklaard en de onderneming tot de boedel behoort'.

\section{De gang van zaken in de Smallsteps-zaak}

Estro Groep BV stond aan het hoofd van een concern dat werkzaam was op het gebied van kinderopvang. Estro Groep BV was de enige aandeelhouder en

1 Richtlijn 77/187/EEG van de Raad van 14 februari 1977 inzake de onderlinge aanpassing van de wetgevingen der lidstaten betreffende het behoud van de rechten van de werknemers bij overgang van ondernemingen, vestigingen of onderdelen van ondernemingen of vestigingen (PbEG 1977, L 61/26), Richtlijn 98/50/EG van de Raad van 29 juni 1998 tot wijziging van Richtlijn 77/187/EEG inzake de onderlinge aanpassing van de wetgevingen der lidstaten betreffende het behoud van de rechten van de werknemers bij overgang van ondernemingen, vestigingen of onderdelen van vestigingen (PbEG 1998, L 201/88), en Richtlijn 2001/23/EG van de Raad van 12 maart 2001 inzake de onderlinge aanpassing van de wetgevingen der lidstaten betreffende het behoud van de rechten van de werknemers bij overgang van ondernemingen, vestigingen of onderdelen van ondernemingen of vestigingen (PbEG 2001, L 82/16). 
bestuurder van drie dochtervennootschappen. Dit waren Estro Kinderopvang BV, Estro Services BV, en ook Estro Educatie BV. De groep had ongeveer 380 kinderopvangbedrijven in Nederland. Bij de groep waren ongeveer 3600 werknemers werkzaam. De Estro-groep stond er sinds het einde van 2013 financieel slecht voor. Op 5 juni 2014 hebben Estro Groep BV, Estro Kinderopvang BV en Estro Services BV een pre-pack in gang gezet. Zij hebben de Rechtbank Amsterdam gevraagd een zogenoemde beoogd of stille curator (ook wel: beoogd of stille bewindvoerder) aan te wijzen, die na een (aanstaand) faillissement van de Estrovennootschappen tot curator zou kunnen worden benoemd. Die stille curator zou de mogelijkheid moeten hebben om samen met (de besturen van) de vennootschappen een doorstart van onderdelen van de Estro-groep voor te bereiden (onder toezicht van een beoogd of stille rechter-commissaris), zodat die doorstart onmiddellijk na het faillissement (dat de Estro-vennootschappen zelf zouden aanvragen) zou kunnen plaatsvinden.

De rechtbank heeft de pre-pack deels gehonoreerd. Zij heeft een stille curator benoemd die geen voorbereidingshandelingen voor een doorstart mocht verrichten, maar zich alleen mocht laten informeren over de toestand van de Estro-vennootschappen. De Estro-vennootschappen zijn op 5 juli 2014 failliet verklaard.

Op 5 juli 2014, de dag van de faillissementen, heeft de rechtbank de stille curator benoemd tot curator. De curator heeft diezelfde dag een overeenkomst gesloten met Smallsteps BV, waarbij Smallsteps BV 250 kinderopvangbedrijven en 2600 werknemers overnam. De curator sloot de overeenkomst met Smallsteps BV ondanks bezwaren tegen de gang van zaken. Twee grote aandeelhouders van Estro Groep BV waren de private equity-fondsen KKK en Bayside Capital. Hun opgetelde aandelenpercentage was ongeveer $79,7 \%$. Estro Groep BV had met deze aandeelhouders gesproken over een doorstart. Nadat KKK haar aandelenbelang had overgedragen aan Bayside Capital, gingen de gesprekken door met Bayside Capital, die daarbij ook haar groepsmaatschappij H.I.G. Capital betrok. De curator had het juister gevonden als Estro Groep BV ook met andere partijen zou hebben gesproken over een mogelijke doorstart. Daar kwam bij dat de bestuursvoorzitter van Estro Groep BV en een lid van de raad van commissarissen van Estro Groep BV na de doorstart betrokken zouden blijven bij de doorgestarte onderneming. In een verslag van werkzaamheden van 5 juli 2014 schreef de (toen nog stille) curator hierover:

'De stille bewindvoerder heeft vanwege het gemankeerde biedingsproces aanvankelijk overwogen om niet eens meer kennis te nemen van de onderhandelingen omtrent de beoogde doorstart of zelfs zijn werkzaamheden geheel te staken. Gelet op de grote maatschappelijke consequenties heeft de stille bewindvoerder dit, in overleg met de stille rechter-commissaris, uiteindelijk niet gedaan.'

De stille curator gebruikte in verband met Bayside Capital en H.I.G. Capital de term 'connected parties'. Onder de werknemers die geen nieuwe arbeidsovereen- 
komsten aangeboden kregen door Smallsteps BV bevonden zich ook werknemers die werkzaam waren in kinderopvangbedrijven die wel door Smallsteps BV waren overgenomen.

Volgens Federatie Nederlandse Vakvereniging en de vier werknemers was de regeling betreffende het behoud van de rechten van de werknemers bij overgang van ondernemingen in deze situatie gewoon van toepassing, en gold de uitzondering van art. 7:666 onder a BW niet bij 'een faillissement dat voorafgegaan is door een voorbereidende stille bewindvoering', omdat het hier gebruikte faillissement geen écht faillissement was. Dit faillissement was immers niet 'gericht (...) op liquidatie', maar was 'gericht (...) op continuïteit en reorganisatie'. Federatie Nederlandse Vakvereniging en de vier werknemers hebben Smallsteps BV gedagvaard voor de Rechtbank Midden-Nederland.

\section{De uitspraak van het Europese Hof van Justitie}

Het Europese Hof van Justitie beantwoordde de prejudiciële vragen op 22 juni 2017. ${ }^{2}$ Het Hof wees erop dat art. 5 lid 1 van de richtlijn een uitzonderingsbepaling is, die 'noodzakelijkerwijs' restrictief moet worden uitgelegd (par. 41). De uitzondering van art. 5 lid 1 is afhankelijk van drie cumulatieve voorwaarden: (1) er moet sprake zijn van een faillissementsprocedure (of een soortgelijke procedure); (2) deze procedure moet als doel hebben het vermogen te liquideren; en (3) deze procedure moet onder toezicht staan van een overheidsinstantie (par. 44). Een pre-pack, die weliswaar wordt voorbereid vóór een faillissement, maar wordt uitgevoerd ná een faillissement, zou op zichzelf aan deze drie voorwaarden kunnen voldoen (par. 46). Maar het Hof overwoog vervolgens in paragraaf 49, 50 en 51 (die de kernoverwegingen zijn):

'In casu blijkt uit de verwijzingsbeslissing dat een pre-pack zoals die welke in het hoofdgeding aan de orde is, tot in de kleinste details de overdracht van de onderneming beoogt voor te bereiden om na de faillietverklaring een snelle doorstart mogelijk te maken van de levensvatbare onderdelen van de onderneming, teneinde op die manier de onderbreking te vermijden die het gevolg zou zijn van de plotselinge stopzetting van de activiteiten van die onderneming op de datum van de faillietverklaring, zodat de waarde van de onderneming en de werkgelegenheid behouden blijven.' (par. 49)

Met als conclusie dat

'[o]nder deze omstandigheden (...), moet worden vastgesteld dat een dergelijke transactie uiteindelijk niet de liquidatie van de onderneming beoogt, zodat het economische en sociale doel daarvan [dat is: van die transactie, dus

2 HvJ EU 22 juni 2017, C-126/16, ECLI:EU:C:2017:489, JAR 2017/189, JOR 2017/217 (Federatie Nederlandse Vakvereniging, K. van den Burg-Vergeer, L.T.A. Kukupessy, D. Paase-Teeuwen, A.J.G.P. Schenk/Smallsteps BV). 
van de pre-pack; CdG] noch kan verklaren noch kan rechtvaardigen dat bij een volledige of gedeeltelijke overgang van de betrokken onderneming, haar werknemers worden beroofd van de rechten die richtlijn 2001/23 hun toekent'. (par. 50)

En dat

'de omstandigheid dat de pre-pack tevens gericht kan zijn op een zo hoog mogelijke uitbetaling aan de schuldeisers, niet tot gevolg [kan] hebben dat deze hierdoor een procedure wordt die is ingeleid met het oog op de liquidatie van het vermogen van de vervreemder in de zin van artikel 5, lid 1, van richtlijn 2001/23'. (par. 51)

Deze uitspraak van het Europese Hof van Justitie laat weinig ruimte voor interpretatie. De upshot is duidelijk: een pre-pack valt in het algemeen niet onder de faillissementsuitzondering van art. 5 lid 1 van de richtlijn, zodat de hoofdregel van de richtlijn van toepassing blijft. Die hoofdregel is dat bij de overgang van een onderneming of van een onderdeel daarvan de rechten en verplichtingen uit arbeidsovereenkomsten automatisch mee overgaan. Oftewel: de werknemers in de onderneming of in het onderdeel daarvan worden automatisch werknemer van de verkrijger. Loesberg schrijft in positieve zin over de uitspraak van het Hof:

'Dat geen beroep op art. 5 [van de richtlijn] mogelijk is indien de vervreemder niet de liquidatie van zijn vermogen beoogt, vormt een effectieve remedie tegen misbruik en daarom vind ik de overweging van het Hof aanvaardbaar. Treden de werknemers per definitie niet van rechtswege in dienst van de verkrijger ook in het geval van een voor de faillietverklaring voorbereide doorstart, dan staan zij in beginsel met lege handen.'3

De Nederlandse rechtspraak na de Smallsteps-uitspraak heeft tot beduidend gemengde(re) reacties geleid.

\section{De Nederlandse rechtspraak na de Smallsteps-uitspraak}

\subsection{Heiploeg}

Het Heiploeg-concern was werkzaam op het gebied van (met name) de groothandel in garnalen. Het was een internationaal concern met in Nederland als vennootschappen onder meer Heiploeg Holding BV en Noord Zuid Beheer BV (die beide houdstervennootschappen waren), Heiploeg BV (de belangrijkste werkmaatschappij), Heitrans BV (de transportmaatschappij van het concern) en Heiploeg Seafood BV (de personeelsvennootschap). Het concern heeft in 2011 en 2012 aanmerkelijke verliezen geleden. In 2013 legde de Europese Commissie het concern een grote boete op. Dit alles was aanleiding voor het concern om een 
doorstart te overwegen, in de vorm van een pre-pack. Het concern heeft met drie partijen gesproken die bereid waren onderdelen van het concern voort te zetten. Het concern heeft met één partij verder gesproken. Op 15 januari 2014 heeft het concern de rechtbank verzocht een stille curator (en een stille rechter-commissaris) aan te stellen. Op 16 januari 2014 heeft de rechtbank twee stille curatoren aangesteld. Op 27 januari 2014 hebben de Heiploeg-vennootschappen het eigen faillissement aangevraagd. De rechtbank heeft de vennootschappen op 28 januari 2014 failliet verklaard, en de stille curatoren benoemd tot curatoren.

Het doorgestarte Heiploeg-concern bestond onder meer uit Heiploeg Holding International BV (waarvan de aandeelhouder de partij was die bereid was de doorstart vorm te geven), Heiploeg Seafood International BV (de personeelsvennootschap) en Heiploeg International BV (de werkmaatschappij). Het doorgestarte Heiploeg-concern heeft met 210 (van de ongeveer 300) werknemers nieuwe arbeidsovereenkomsten gesloten. Federatie Nederlandse Vakbeweging en CNV Vakmensen hebben een vordering ingesteld tegen Heiploeg Seafood International BV en Heitrans International BV. Zij stelden zich (in de kern) op het standpunt dat alle werknemers van Heiploeg BV (de belangrijkste werkmaatschappij), Heitrans BV (de transportmaatschappij van het concern) en Heiploeg Seafood BV automatisch werknemer waren geworden van Heiploeg Seafood International BV en Heiploeg International BV (en dat de faillissementsuitzondering van art. 7:666 onder a BW dus niet van toepassing was). De rechtbank heeft de vordering afgewezen. ${ }^{4}$ Het vonnis van de rechtbank, van 28 juli 2015, dateert van vóór de uitspraak van het Europese Hof van Justitie van 22 juni 2017. Federatie Nederlandse Vakbeweging en CNV Vakmensen hebben hoger beroep ingesteld. Het hof deed uitspraak op 17 juli 2018, ${ }^{5}$ dus ná de uitspraak van het Europese Hof van Justitie. Het hof heeft het vonnis van de rechtbank bekrachtigd. Het hof wees op het volgende:

'De curatoren in het faillissement van Heiploeg-oud hebben in een door Heiploeg-nieuw (...) in het geding gebrachte verklaring aangegeven dat zij zich in de periode voorafgaand aan het faillissement uitsluitend hebben gericht op de liquidatie van het vermogen van Heiploeg-oud en dat zij in dat kader hebben beoordeeld of een verkoop van de activa "going concern" in het belang van de schuldeisers was.' (r.o. 2.10)

De daaropvolgende stappen in de redenering van het hof waren:

- 'Naar het oordeel van het hof moet uit de hiervoor omschreven omstandigheden worden opgemaakt dat, anders dan de bonden aanvoeren, de faillissementsprocedure wel degelijk is ingeleid met het oog op de liquidatie van het

4 Rb. Overijssel (team kanton en handelsrecht) 28 juli 2015, ECLI:NL:RBOVE:2015:3589, JAR 2015/220, JOR 2015/282 (FNV en CNV Vakmensen/Heiploeg Seafood International BV en Heitrans International BV).

5 Hof Arnhem-Leeuwarden 17 juli 2018, ECLI:NL:GHARL:2018:6539, JAR 2018/218, JOR 2018/265 (Federatie Nederlandse Vakbeweging en CNV Vakmensen/Heiploeg Seafood International BV en Heitrans International BV). 
vermogen van Heiploeg-oud. Dat reeds voorafgaand aan het faillissement contacten zijn opgenomen met geïnteresseerde partijen over een verkoop als going concern en daarover vervolgens met één partij onderhandelingen zijn gevoerd (...) doet daaraan niet af' (r.o. 2.11).

- Op 28 januari 2014, de dag van de faillissementen, 'was er (...) nog geen overeenstemming over de verkoop van de activa. Er is verder onderhandeld en pas in de nacht van 28 op 29 januari 2014 is uiteindelijk overeenstemming bereikt. Op dat moment waren de curatoren als enigen bevoegd om namens Heiploeg-oud op te treden' (r.o. 2.12).

- Toen die overeenstemming werd bereikt, heeft de rechter-commissaris toestemming verleend voor de transactie: 'Dit betekent naar het oordeel van het hof dat de overeenkomst is gesloten onder toezicht van een bevoegde overheidsinstantie als bedoeld in artikel 5 lid 1 van de richtlijn' (r.o. 2.12).

\section{- Commentaar}

In de Heiploeg-zaak was onmiskenbaar sprake van een pre-pack: het concern onderhandelde met drie partijen over een doorstart, en zette de onderhandelingen voort met één partij. Het concern verzocht de rechtbank een stille curator aan te stellen; de rechtbank deed dat op 15 januari 2014. Op 27 januari 2014 vroegen de Heiploeg-vennootschappen hun eigen faillissement aan, dat op 28 januari 2014 werd uitgesproken en waarbij de stille curatoren werden benoemd tot curator. In de nacht van 28 op 29 januari 2014 bereikten de curatoren overeenstemming met de nieuwe aandeelhouder over de doorstart. Desondanks komt het Gerechtshof Arnhem-Leeuwarden tot het oordeel dat de faillissementsuitzondering moet worden toegepast. De redenering van het hof is wonderlijk. Uit onder meer een verklaring van de curatoren 'dat zij zich in de periode voorafgaand aan het faillissement uitsluitend hebben gericht op de liquidatie van het vermogen van Heiploeg-oud' leidt het hof af dat 'de faillissementsprocedure wel degelijk is ingeleid met het oog op de liquidatie van het vermogen van Heiploeg-oud'. Het hof voegt daaraan toe dat, na de faillissementen op 28 januari 2014, de curatoren en de partij die tot een doorstart bereid was 'pas in de nacht van 28 op 29 januari 2014' (cursivering CdG) tot een definitief akkoord kwamen. Van der Pijl schrijft hierover:

'Mijn onbegrip betreft het gegeven dat het hof kennelijk in het toezicht dat gedurende minder dan 24 uur is uitgeoefend (...) voldoende aanleiding ziet de op dit punt duidelijke overwegingen van de Europese rechter terzijde te stellen. Dit zou in de hand werken dat voortaan een middag of avond voor de bühne wordt dooronderhandeld om zodoende de rechten van werknemers, gewaarborgd in de richtlijn, te omzeilen.' 
Iets terughoudender schrijft Loesberg:

'Het lijkt erop dat de stille bewindvoerder (en de beoogd rechter-commissaris) op het moment van de faillietverklaring de handen niet meer vrij had en dat moet ertoe leiden dat een beroep op de uitzondering van art. 5 van de richtlijn niet mogelijk is." ${ }^{\text {? }}$

\subsection{Bogra}

Bogra BV vervaardigde uitvaartkisten. Zij was een dochtervennootschap van Bogra Beheer BV, die weer een dochtervennootschap was van Rocca Holding BV. In mei 2017 kwam het Rocca-concern in financiële problemen. Bogra BV (en een andere concernvennootschap, Rouwservice Nederland BV) is op 30 juni 2017 failliet verklaard. Op diezelfde dag heeft de curator de arbeidsovereenkomsten van de werknemers beëindigd. Voorafgaand aan het faillissement, in de periode van 22 tot en met 26 juni 2017, had Bogra BV gesproken met de Belgische vennootschap Funico NV over een mogelijke doorstart. De - later - op 30 juni 2017 benoemde curator was één dag betrokken geweest bij die gesprekken, maar had zich op 23 juni 2017 (de dag na de Smallsteps-uitspraak van het Europese Hof van Justitie) teruggetrokken. Vanaf de faillissementsdatum hebben verschillende partijen met de curator gesproken over de mogelijkheden van een doorstart van Bogra BV. Op 18 juli 2017 heeft de curator een overeenkomst gesloten met Funico NV over een doorstart. Die overeenkomst hield in dat een deel van de activiteiten van Bogra BV vanaf 19 juli 2017 werd voortgezet door Bogra Uitvaartkisten BV (die daartoe op 17 juli 2017 was opgericht). Bogra Uitvaartkisten BV heeft met ongeveer 35 van de ongeveer 60 werknemers van Bogra BV nieuwe arbeidsovereenkomsten gesloten. Zeven werknemers, met wie Bogra Uitvaartkisten BV geen nieuwe arbeidsovereenkomst aanging, hebben een vordering ingesteld tegen Bogra Uitvaartkisten BV. Zij stelden zich op het standpunt dat zij op grond van art. 7:663 BW na de doorstart automatisch werknemer waren geworden van Bogra Uitvaartkisten BV. Zij waren meer concreet van mening dat omdat Bogra Uitvaartkisten BV hun arbeidsovereenkomsten niet wilde continueren, Bogra Uitvaartkisten BV een beëindigingsvergoeding verschuldigd was. De Rechtbank Noord-Holland heeft deze vordering op 12 oktober 2017 afgewezen. ${ }^{8}$ Naar het oordeel van de rechtbank was geen sprake van een overgang van een onderneming, maar was de uitzonderingsbepaling van art. 7:666 onder a BW inzake faillissement van toepassing. De zeven werknemers hebben hoger beroep ingesteld; het hof heeft de beslissing van de rechtbank bekrachtigd. ${ }^{9}$ Het hof overwoog dat er in dit geval geen pre-pack à la Smallsteps was geweest, zodat de redenering van het Europese Hof van Justitie in die zaak niet zonder meer van toepassing was:

7 E. Loesberg, noot onder JOR 2018/265.

8 Rb. Noord-Holland (sector kanton) 12 oktober 2017, ECLI:NL:RBNHO:2017:8423, JAR 2017/281, JOR 2017/338 (zeven verzoek(st)ers/Bogra Uitvaartkisten BV).

9 Hof Amsterdam 10 juli 2018, ECLI:NL:GHAMS:2018:2339, JAR 2018/216, JOR 2018/264 (zeven verzoek(st)ers/Bogra Uitvaartkisten BV). 
'Het hof overweegt dat de onderhavige situatie wezenlijk afwijkt van de situatie zoals deze zich voordeed in Smallsteps. Van een pre-pack in de zin van deze uitspraak is geen sprake, zoals ook [de zeven werkne(e)m(st)ers] lijken te hebben erkend. De op 22 juni 2017 gesloten overeenkomst tot stille bewindvoering was immers (al) op 23 juni 2017 beëindigd.' (r.o. 3.7)

En:

'Zoals reeds in r.o. 3.7 is geoordeeld, is in de onderhavige kwestie geen sprake geweest van een pre-pack in de zin van Smallsteps. Voor een ruimere uitleg van Smallsteps als door [de zeven werkne(e)m(st)ers] is bepleit, ziet het hof in casu geen aanleiding, alleen al niet omdat geenszins is komen vast te staan dat met Funico voorafgaand aan het faillissement op hoofdlijnen overeenstemming over de overdracht van (de activa van) de onderneming was bereikt.' (r.o. 3.9)

\section{- Commentaar}

In de Bogra-zaak was geen sprake van een pre-pack. Bogra BV had zelf gesproken met de Belgische vennootschap Funico NV over een mogelijke doorstart, en de later benoemde curator was maar één dag betrokken geweest bij die gesprekken. In deze zaak betoogden de zeven werknemers dat dit geval op dezelfde manier moest worden behandeld als een pre-pack, zodat de faillissementsuitzondering niet van toepassing was. Deze redenering is alleszins verdedigbaar. Net als bij een pre-pack vonden in de Bogra-zaak de onderhandelingen over de doorstart plaats voor het faillissement, en net als bij een pre-pack finaliseerde in de Bogra-zaak de curator de doorstart na het faillissement. Van der Pijl schrijft in dit verband:

'In deze zaak waren voldoende feiten en omstandigheden voorhanden, zo lijkt het, om te stellen dat de procedure niet louter werd ingeleid om tot liquidatie en opbrengstmaximalisatie voor de schuldeisers over te gaan. ${ }^{10}$

Loesberg komt tot de volgende conclusie:

'Wat mij betreft is de beschikking van het hof in zoverre onbevredigend. Zou sprake zijn van een vóór de surseance en faillietverklaring geregisseerde doorstart die geruime tijd na de faillietverklaring is gerealiseerd om geen "Smallsteps-problemen" te krijgen, dan is geen sprake van een neutrale curator die zich eerst na zijn benoeming heeft gecommitteerd. Dan is wat mij betreft een beroep op art. 5 van de richtlijn niet mogelijk en zou de conclusie moeten zijn dat de werknemers van Bogra van rechtswege in dienst zijn getreden van Bogra Uitvaartkisten.' 11 
Loesberg lijkt er hier de nadruk op te leggen dat een curator die als stille curator voorafgaand aan het faillissement op enigerlei wijze al betrokken was bij de pogingen tot een doorstart, na het faillissement de handen niet meer helemaal vrij heeft om het vermogen van de failliete vennootschap te liquideren. In dat geval wordt een beroep op de faillissementsuitzondering wel erg moeilijk.

\subsection{Tuunte}

Tuunte Holding BV had een aantal dochtervennootschappen, waaronder Tuunte Fashion BV en Tuunte 'wat de dag ook brengt' BV. Die laatste vennootschap had twintig dochtervennootschappen, namelijk Tuunte 1 'je ziet er goed uit' BV tot en met Tuunte 20 'je ziet er goed uit' BV. De Tuunte-groep hield zich bezig met verschillende activiteiten, zoals het exploiteren van (mode)winkels en een webshop. De werknemers van de Tuunte-groep waren in dienst van Tuunte Fashion BV. Tuunte Fashion BV is op 8 augustus 2017 failliet verklaard. De curator heeft de arbeidsovereenkomsten van alle werknemers beëindigd. Op 29 augustus 2017 is ook een aantal van de Tuunte 'je ziet er goed uit'-vennootschappen failliet verklaard. Op 7 september 2017 heeft de curator een overeenkomst gesloten met Roose BV en Zoef Investments BV om een doorstart van een aantal winkels van de failliete vennootschappen mogelijk te maken. Een aantal ontslagen werknemers (113) heeft een vordering ingesteld tegen onder meer Roose BV en Zoef Investments BV. Zij stelden zich op het standpunt dat zij na de doorstart automatisch werknemer waren geworden van Roose BV en/of Zoef Investments BV. Zij eisten dan ook dat Roose BV en/of Zoef Investments BV hen zouden toelaten tot hun werkzaamheden in de overgenomen winkels waarin zij hadden gewerkt. Zij beriepen zich op art. 7:663 BW. Er was naar hun mening weliswaar sprake van een overgang van een onderneming in faillissement, maar zij stelden dat de doorstart al vóór het faillissement van Tuunte Fashion BV was voorbereid. Zij voerden met name aan dat op 7 augustus 2017 een vennootschap was opgericht (GhiDo Exploitatie BV) en dat de indirecte voormalige aandeelhouder en bestuurder van Tuunte Fashion BV ook bestuurder was van deze GhiDo Exploitatie BV. Verder wezen ze erop dat GhiDo Exploitatie BV aandeelhouder was van Roose BV. De rechtbank verwierp deze argumentatie en wees de vordering af. ${ }^{12}$ De rechtbank overwoog (1) dat sowieso geen sprake was van een pre-pack waarin een beoogd curator was aangesteld, en (2):

'(...) dat de betrokken bestuurders van Tuunte Fashion er uiteraard van op de hoogte waren dat een faillissement van Tuunte Fashion zou (kunnen) volgen, (...). Even evident is, dat deze zelfde bestuurders al voor het uitspreken van het faillissement zijn nagegaan of het voor hen zakelijk gezien interessant was om delen van de onderneming, over te dragen aan (een) derde(n) of zelf, al dan niet via nieuw op te richten vennootschappen, te verkrijgen. Uit niets

12 Rb. Gelderland (team kanton en handelsrecht) 1 februari 2018, ECLI:NL:RBGEL:2018:447, JAR 2018/40, JOR 2018/111 (113 verzoekers/Roose BV, Zoef Investments BV, Tuunte 4 'je ziet er goed uit' BV, Tuunte 8 'je ziet er goed uit' BV, Tuunte 11 'je ziet er goed uit' BV en V.F.M. Jongerius (curator)). 
blijkt dat het door de werknemers gestelde "vooropgezette plan" meer behelsde dan het bezien welke delen van de onderneming uit de boedel zouden kunnen worden overgenomen en mogelijk welke prijs hiervoor zou worden geboden.' (r.o. 4.8)

\section{- Commentaar}

Ook in de Tuunte-zaak was geen sprake van een pre-pack. De werknemers van de Tuunte-groep waren in dienst van Tuunte Fashion BV. Na het faillissement van Tuunte Fashion BV op 8 augustus 2017 heeft de curator de arbeidsovereenkomsten van alle werknemers beëindigd. Een aantal van de Tuunte 'je ziet er goed uit'vennootschappen is op 29 augustus 2017 failliet verklaard. Daarna, op 7 september 2017, heeft de curator overeenstemming bereikt met Roose BV en Zoef Investments BV over een doorstart van een aantal winkels. Ook nu betoogden de 113 werknemers dat dit geval op dezelfde manier moest worden behandeld als een pre-pack, zodat de faillissementsuitzondering niet van toepassing was. De Rechtbank Gelderland ging hier niet in mee. Bijloo merkt in dit verband op (overigens met enkele kanttekeningen):

'Al met al lijkt het erop dat de niet-onderbouwde stellingen van de werknemers de kantonrechter in dit specifieke geval de vrijheid hebben geboden om zonder veel uitweiding en dogmatische scherpslijperij tot een verdedigbaar oordeel te komen. ${ }^{13}$

Toch deed zich in deze zaak een omstandigheid voor die opvallend is en wellicht tot een ander oordeel zou moeten leiden. Net als in Smallsteps was sprake van connected parties, waarmee de uitspraak van de rechtbank geen rekening houdt.

\subsection{PGV BV (met als handelsnaam Princen TransMission)}

PGV BV hield zich bezig met de opslag en het vervoer van goederen over land. PGV BV was aangesloten bij een netwerk van transport- en distributiebedrijven dat TransMission BV heette. PGB BV functioneerde als het distributiecentrum van het netwerk. PGB BV is op 31 maart 2015 failliet verklaard. De activiteiten van PGB BV zijn voortgezet door Z BV. De curator in het faillissement van PGV BV heeft de arbeidsovereenkomsten van de werknemers beëindigd. Federatie Nederlandse Vakvereniging en negen werknemers hebben een vordering ingesteld tegen $\mathrm{Z}$ BV. Zij eisten onder meer dat de rechtbank zou vaststellen dat de werknemers van PGV BV automatisch werknemer waren geworden van $\mathrm{Z}$ BV. De rechtbank verwees in haar vonnis uitgebreid naar de Smallsteps-uitspraak van het Europese Hof van Justitie. ${ }^{14}$ De rechtbank vatte de kern van het geschil als volgt samen: 
'FNV c.s. stelt dat het doel van de ingeleide faillissementsprocedure was het doorstarten van de onderneming, terwijl [Z BV] stelt dat het doel was liquidatie van het vermogen van PGV.' (r.o. 3.16)

De rechtbank overwoog dat de stille curator op 20 maart 2015 was benoemd. Vanaf dat moment heeft de bestuurder van de moedervennootschap van PGV BV in samenwerking met de stille curator gesprekken gevoerd met potentiële gegadigden die de werkzaamheden van PGV BV wilden voortzetten. In dit verband overwoog de rechtbank:

'Een faillissement van PGV - dat als distributiecentrum van het netwerk diende - zou tot gevolg hebben dat PGV zou stilvallen met aanzienlijke schade aan het TransMission netwerk als gevolg. PGV, maar zeker TransMission BV had er dan ook alle belang bij dat PGV na faillissement direct zou doorstarten.' (r.o. 3.18)

De uiteindelijke gegadigden waren drie zustervennootschappen van PGB BV (dus net als PGB BV dochtervennootschappen van dezelfde moedervennootschap). De werkzaamheden van PGB BV zijn op 1 april 2016 door één van die dochtervennootschappen (M\&V HR BV, die haar naam op 3 april 2015 wijzigde in Z BV) voortgezet. Dit bracht de rechtbank tot de conclusie dat sprake was van een overgang van de onderneming van PGV BV naar Z BV in de zin van art. 7:663 BW, en dat de uitzondering van art. 7:666 onder a BW in faillissementssituaties niet gold. De rechtbank overwoog in dit verband over de gang van zaken onder meer:

'Dit wijst er sterk op dat er binnen het concern van [de moedervennootschap en haar bestuurder] niet de intentie bestond om het vermogen van PGV te liquideren. Bovendien bevreemdt het de kantonrechter in hoge mate dat er binnen de dochtermaatschappijen van het concern [van de moedervennootschap en haar bestuurder] enerzijds kennelijk wél de financiële middelen bestonden om na faillissement een doorstart te realiseren terwijl er anderzijds niet voor is gekozen om de benodigde financiële impuls te geven teneinde PGV in haar hoedanigheid van distributiecentrum te behouden.' (r.o. 3.19)

Toch was dit niet het einde van het verhaal. De curator had op de dag van de faillietverklaring, 31 maart 2015, de arbeidsovereenkomsten met de werknemers van PGV BV beëindigd. Federatie Nederlandse Vakvereniging en de negen werknemers waren (uiteraard) van mening dat deze beëindiging van de arbeidsovereenkomsten niet rechtsgeldig was omdat de werknemers van PGB BV automatisch werknemer van Z BV waren geworden. De rechtbank honoreerde dit argument uiteindelijk niet. De redenering van de rechtbank was als volgt:

- 'De kantonrechter stelt vast dat de opzegging door de curator, anders dan FNV c.s. betoogt heeft plaatsgevonden voordat er sprake was van een overgang van onderneming. Aldus komt aan de opzegging rechtskracht toe, ook al is die opzegging gedaan met het zicht op - en mogelijk in strijd met het 
opzegverbod geldende in het geval van - de overgang van onderneming' (r.o. 3.32).

- Het vorige punt betekende dat Federatie Nederlandse Vakvereniging en de negen werknemers op grond van het toen geldende arbeidsrecht binnen twee maanden na de beëindiging van de arbeidsovereenkomsten er een beroep op hadden moeten doen dat de beëindigingen niet rechtsgeldig waren. Zij hadden dit te laat gedaan, namelijk (impliciet) in brieven van 9 juni en 21 juni 2015 aan Z BV.

- 'De kantonrechter kan dan ook niet anders dan concluderen dat door de werknemers niet (tijdig) de vernietigbaarheid van de opzegging is ingeroepen en de arbeidsovereenkomsten zijn geëindigd' (r.o. 3.32).

\section{- Commentaar}

De uitspraak van de Rechtbank Limburg heeft twee kanten. Enerzijds stelde de rechtbank vast dat sprake was van een pre-pack, zodat de werknemersbescherming van art. 7:663 BW gold. Anderzijds kwam de rechtbank tot het oordeel dat Federatie Nederlandse Vakvereniging en de negen werknemers de vernietigbaarheid van de beëindiging door de curator van de arbeidsovereenkomsten op 31 maart 2015, de dag van het faillissement, te laat hadden ingeroepen, zodat de werknemersbescherming van art. 7:663 BW toch niet gold. Spinath is het met de eerste conclusie van de rechtbank niet eens. Hij is van mening dat de rechtbank te gemakkelijk oordeelt dat sprake was van een pre-packsituatie waarin de faillissementsuitzondering niet gold. ${ }^{15}$ Wat betreft de tweede conclusie van de rechtbank geldt het volgende: de rechtbank had ook kunnen kiezen voor een redenering die inhoudt dat de werknemersbescherming die voortvloeit uit het recht van de Europese Unie niet, en zeker niet in een geval waarin volgens de rechtbank wel sprake was van een pre-pack zoals bedoeld in het Smallsteps-arrest van het Europese Hof van Justitie, opzij wordt gezet door een nationaalrechtelijke regeling over het tijdig inroepen van de niet-rechtsgeldigheid van de beëindiging van de arbeidsovereenkomsten.

\section{$6 \quad$ Voorgestelde regelgeving}

Het wetsvoorstel Wet continuïteit ondernemingen I probeert de in Nederland gegroeide pre-packpraktijk een wettelijke basis te geven in de Faillissementswet. Dit wetsvoorstel is in behandeling bij de Eerste Kamer. ${ }^{16}$ Het wetsvoorstel is ten gevolge van de uitspraak van het Europese Hof van Justitie on hold gezet. De kern van het wetsvoorstel zijn (de nieuwe) art. 363 tot en met 368 (titel IV 'Buiten faillissement en surseance van betaling', eerste afdeling 'Aanwijzing van een beoogd

16 Kamerstukken I, Wijziging van de Faillissementswet in verband met de aanwijzing door de rechtbank van een beoogd curator ter bevordering van de afwikkeling van een eventueel faillissement en vergroting van de kansen op voortzetting van een onderneming of van een doorstart van rendabele bedrijfsonderdelen (Wet continuïteit ondernemingen I), 34218, A, gewijzigd voorstel van wet (21 juni 2016). 
curator'). Op grond van het voorgestelde art. 363 lid 1 kan de rechtbank op verzoek van een schuldenaar 'ter voorbereiding van een dreigend faillissement een of meer personen aanwijzen die in geval van faillietverklaring zullen worden aangesteld als curator', mits 'deze voorbereiding meerwaarde heeft'. Van meerwaarde is sprake als de aanwijzing van een stille curator 'de schade voor de betrokkenen bij het eventuele faillissement in zodanige mate kan beperken', of 'de kans op een verkoop van rendabele onderdelen van de door de schuldenaar gedreven onderneming na de eventuele faillietverklaring tegen een zo hoog mogelijke verkoopprijs en met behoud van zoveel mogelijk werkgelegenheid in zodanige mate kan vergroten', 'dat dit opweegt tegen de omstandigheid dat de voorbereiding in stilte plaatsvindt'.

Bij brief van 11 april 2018 aan de voorzitter van de Eerste Kamer der StatenGeneraal verzocht de minister voor Rechtsbescherming de behandeling van het wetsvoorstel voort te zetten, waarbij de regering rekening zou houden met 'de noodzaak van een regeling betreffende de positie van werknemers bij een doorstart in faillissement waarmee de uitspraak van het EU-hof een concretisering in onze wetgeving zou kunnen krijgen'. ${ }^{17}$ In vervolg daarop is op 29 mei 2019 het voorontwerp Wet overgang van onderneming in faillissement gepubliceerd. ${ }^{18} \mathrm{Dit}$ voorontwerp haalt de faillissementsuitzondering uit art. 7:666 onder a BW weg. De kern van het wetsvoorstel is vervolgens het (nieuwe) art. 7:666b BW.

Lid 1 van art. 7:666b BW luidt:

'Zijn de arbeidsovereenkomsten tussen de gefailleerde werkgever en de werknemers die op de dag van de faillietverklaring nog in de onderneming werkzaam zijn, inmiddels overeenkomstig artikel 40 van de Faillissementswet door de curator opgezegd, dan doet de verkrijger deze werknemers een aanbod tot het sluiten van een arbeidsovereenkomst op basis waarvan zij op het moment van de overgang bij hem in dienst treden.'

Lid 2 van art. 7:666b BW voegt daaraan toe:

'Lid 1 is niet van toepassing als niet alle werknemers in dienst kunnen worden genomen, omdat te voorzien is dat er binnen 26 weken na de overgang noodzakelijkerwijs arbeidsplaatsen vervallen als gevolg van het wegens bedrijfseconomische omstandigheden treffen van maatregelen voor een doelmatige bedrijfsvoering (...). In dat geval doet de verkrijger voor iedere

17 Kamerstukken I, Wijziging van de Faillissementswet in verband met de aanwijzing door de rechtbank van een beoogd curator ter bevordering van de afwikkeling van een eventueel faillissement en vergroting van de kansen op voortzetting van een onderneming of van een doorstart van rendabele bedrijfsonderdelen (Wet continuïteit ondernemingen I), 34218, J, brief van de minister voor Rechtsbescherming (11 april 2018).

18 Wijziging van Boek 7 van het Burgerlijk Wetboek en enige andere wetten in verband met de introductie van een regeling betreffende de rechten van de werknemer bij overgang van een onderneming in faillissement (Wet overgang van onderneming in faillissement); www.internetconsultatie.nl. 
arbeidsplaats die behouden blijft één van de werknemers een aanbod tot het sluiten van een arbeidsovereenkomst als bedoeld in lid 1. De verkrijger hanteert een objectieve selectiemethode op basis waarvan bepaald wordt in welke volgorde de werknemers dit aanbod krijgen.'

Art. 7:666b lid 1 en 2 BW bevatten een radicale koerswijziging. In plaats van de faillissementsuitzondering in het huidige art. 7:666 onder a BW bepaalt het voorgestelde lid 1 dat bij een overgang van een onderneming in faillissement de verkrijger van de onderneming aan de werknemers die door de curator zijn opgezegd, nieuwe arbeidsovereenkomsten moet aanbieden. Het voorgestelde lid 2 is ingegeven door de tweede volzin van art. 4 lid 1 van de richtlijn:

'[De richtlijn] vormt geen beletsel voor ontslagen om economische, technische of organisatorische redenen die wijzigingen voor de werkgelegenheid met zich brengen.'

Dit voorgestelde lid 2 maakt het voor de verkrijger mogelijk aan slechts een deel van de werknemers nieuwe arbeidsovereenkomsten aan te bieden. Dit kan de verkrijger doen 'wegens bedrijfseconomische omstandigheden' en op grond van 'een objectieve selectiemethode'. ${ }^{19}$ Het voorgestelde lid 4 van art. 7:666b BW breidt de werknemersbescherming nog verder uit, ${ }^{20}$ en het voorgestelde lid 5 geeft werknemers aan wie geen nieuwe arbeidsovereenkomst is aangeboden de mogelijkheid zich tot de rechter te wenden:

'Heeft een werknemer geen aanbod gekregen tot het sluiten van een arbeidsovereenkomst als bedoeld in de leden 1, 2 en 4, terwijl hij daar wel voor in aanmerking had moeten komen, dan kan de kantonrechter op zijn verzoek de verkrijger veroordelen om:

a de werknemer een aanbod te doen tot het sluiten van een arbeidsovereenkomst als bedoeld in lid 1 ;

b de werknemer een aanbod te doen tot het sluiten van een arbeidsovereenkomst als bedoeld in lid 4, waarbij de werknemer op een door de kantonrechter te bepalen datum bij de verkrijger in dienst treedt, of

c aan de werknemer ten laste van de verkrijger een billijke vergoeding toekennen, als het alsnog in dienst komen bij de verkrijger in redelijkheid voor Rechtsbescherming: (...) worden regels gesteld over de objectieve selectiemethode.' Het voorontwerp Regeling overgang van onderneming in faillissement staat eveneens op www.internetconsultatie.nl.

20 'Zijn wegens de in lid 2 genoemde grond niet alle werknemers door de verkrijger in dienst genomen, maar ontstaat er binnen 26 weken na de overgang binnen de onderneming een vacature voor dezelfde of vergelijkbare werkzaamheden als die welke werden verricht door een werknemer als bedoeld in lid 1, dan doet de verkrijger één van de werknemers aan wie hij nog geen aanbod heeft gedaan tot het sluiten van een arbeidsovereenkomst, alsnog dit aanbod. De verkrijger hanteert daarbij de objectieve selectiemethode bedoeld in lid 2.' 
niet mogelijk is vanwege ernstig verwijtbaar handelen of nalaten van de verkrijger.'

In alle gevallen waarin de verkrijger nieuwe arbeidsovereenkomsten aanbiedt, geldt dat zo'n arbeidsovereenkomst 'voor wat betreft de rechten en verplichtingen van de verkrijger jegens de werknemer en die van de werknemer jegens de verkrijger gelijk [is] aan de arbeidsovereenkomst tussen de werknemer en de gefailleerde werkgever'.

Het is de vraag of het voorontwerp Wet overgang van onderneming in faillissement in overeenstemming is met de richtlijn. ${ }^{21}$ De richtlijn bepaalt dat een overgang van een onderneming automatisch meebrengt dat de werknemers mee overgaan (art. 3 lid 1). Dat geldt niet in een faillissementssituatie:

'Tenzij de lidstaten anders bepalen, zijn de artikelen 3 en 4 niet van toepassing op een overgang van een onderneming, vestiging of een onderdeel van een onderneming of vestiging wanneer de vervreemder verwikkeld is in een faillissementsprocedure.' (art. 5 lid 1)

Deze bepaling geeft de lidstaten een keuze: de richtlijn is in een faillissementsprocedure niet van toepassing, tenzij een lidstaat ervoor kiest om de richtlijn wel van toepassing te laten zijn. Er is geen reden om aan te nemen dat een lidstaat, naast deze keuze, een eigen regime mag ontwikkelen voor de overgang van een onderneming in faillissement dat afwijkt van de richtlijn. De keuze is nee, of ja, maar niet een soort ja light. En dat laatste is wat het voorontwerp doet. De werknemers gaan in het voorontwerp niet automatisch over (waarna het aan de overnemer is om hen te ontslaan om (door de richtlijn toegelaten) economische, technische of organisatorische redenen), maar de overnemer kan (en moet) de werknemers van de vervreemder arbeidsovereenkomsten aanbieden. Laat de overnemer dat na, of is de door de overnemer gehanteerde selectiemethode onjuist, dan zijn de werknemers gedwongen zelf actie te ondernemen door een procedure te beginnen bij de kantonrechter. Zij hebben dan niet, om de woorden van het Europese Hof van Justitie in Smallsteps te gebruiken, 'de rechten die richtlijn 2001/23 hun toekent'. Interessant in dit verband, en een (zij het indirecte) ondersteuning van het hier verdedigde standpunt, is dat de (aanstaande) richtlijn van het Europees Parlement en de Raad betreffende preventieve herstructureringsstelsels in art. 13 ('Werknemers') bepaalt dat de lidstaten ervoor moeten zorgen dat nationale preventieve herstructureringsstelsels geen afbreuk mogen doen aan (onder meer)

21 Vgl. HvJ EU 16 mei 2019, C-509/17, ECLI:EU:C:2019:424 (Christa Plessers/Prefaco NV en de Belgische Staat); en ook: de reactie op de internetconsultatie door F. De Leo (Instituut voor Handels- en Insolventierecht, KU Leuven, UHasselt, België, 3 juni 2019). 
Richtlijn 2001/23/EG betreffende het behoud van de rechten van de werknemers bij overgang van ondernemingen. ${ }^{22}$

\section{Conclusie}

Wat betreft de waardering van de Nederlandse rechtspraak na het Smallstepsarrest van het Europese Hof van Justitie tekent zich een tweedeling af. Voorbeelden hiervan zijn de meningen van Spinath en Van der Pijl. Spinath schrijft:

'Het lijkt erop dat rechters vooralsnog zo weinig mogelijk betekenis toekennen aan Smallsteps en dat is naar mijn mening een goede ontwikkeling. ${ }^{23}$

Van der Pijl schrijft over de beslissing in de Bogra-zaak:

'Het gerechtshof gaat (...) na of er aanleiding bestaat voor wat hij noemt "analoge toepassing van Smallsteps". Daarbij knoopt hij aan bij een aantal in Smallsteps gehanteerde termen. Er lag, aldus het hof, geen "tot in de kleinste details uitgewerkt plan" klaar en de overdracht heeft niet "onmiddellijk na de faillietverklaring" plaatsgevonden, zoals bij Smallsteps. Dat is op zichzelf juist, in Smallsteps lagen de kaarten anders. Maar is dat doorslaggevend? Ik meen van niet.'24

De woorden van het Europese Hof van Justitie over een pre-pack zijn duidelijk: omdat een pre-pack 'uiteindelijk niet de liquidatie van de onderneming beoogt', kan het niet zo zijn 'dat bij een volledige of gedeeltelijke overgang van de betrokken onderneming, haar werknemers worden beroofd van de rechten die richtlijn 2001/23 hun toekent'. In die zin moet de conclusie zijn dat de Nederlandse rechtspraak na Smallsteps niet of te weinig rekening houdt met de beslissing van het Hof. Dat geldt niet alleen voor de rechtspraak. Ook het voorontwerp Wet overgang van onderneming in faillissement is waarschijnlijk niet richtlijnproof. Het voorontwerp gaat niet uit van automatische overgang van de arbeidsovereenkomsten op de verkrijger, maar dwingt de niet-overgenomen werknemers zelf een procedure aan te spannen. Dat is strijdig met de automatische overgang van werknemers die het uitgangspunt is van de richtlijn.

22 Vgl. de Wetgevingsresolutie van het Europees Parlement van 28 maart 2019 over het voorstel voor een richtlijn van het Europees Parlement en de Raad betreffende preventieve herstructureringsstelsels, een tweede kans en maatregelen ter verhoging van de efficiëntie van herstructurerings-, insolventie- en kwijtingsprocedures, en tot wijziging van Richtlijn 2012/30/EU (COM(2016)0723 - C8-0475/2016 - 2016/0359(COD)), aangenomen op 28 maart 2019 (nr. P8_TA(2019)0321).

23 I. Spinath, noot onder JOR 2018/316.

24 J. van der Pijl, noot onder JAR 2018/216. 